\title{
European Journal of
}

\section{Business and Strategic Management}

(EJBSM)

\section{EFFECT OF TANGIBILITY ON CUSTOMER SATISFACTION AMONG MICRO FINANCE BANKS CUSTOMERS IN KENYA}

Hakim Omondi Nyabundi, Dr. Victor Lusala Aliata, PhD, Dr. Alphonce Odondo, $\mathrm{PhD}$

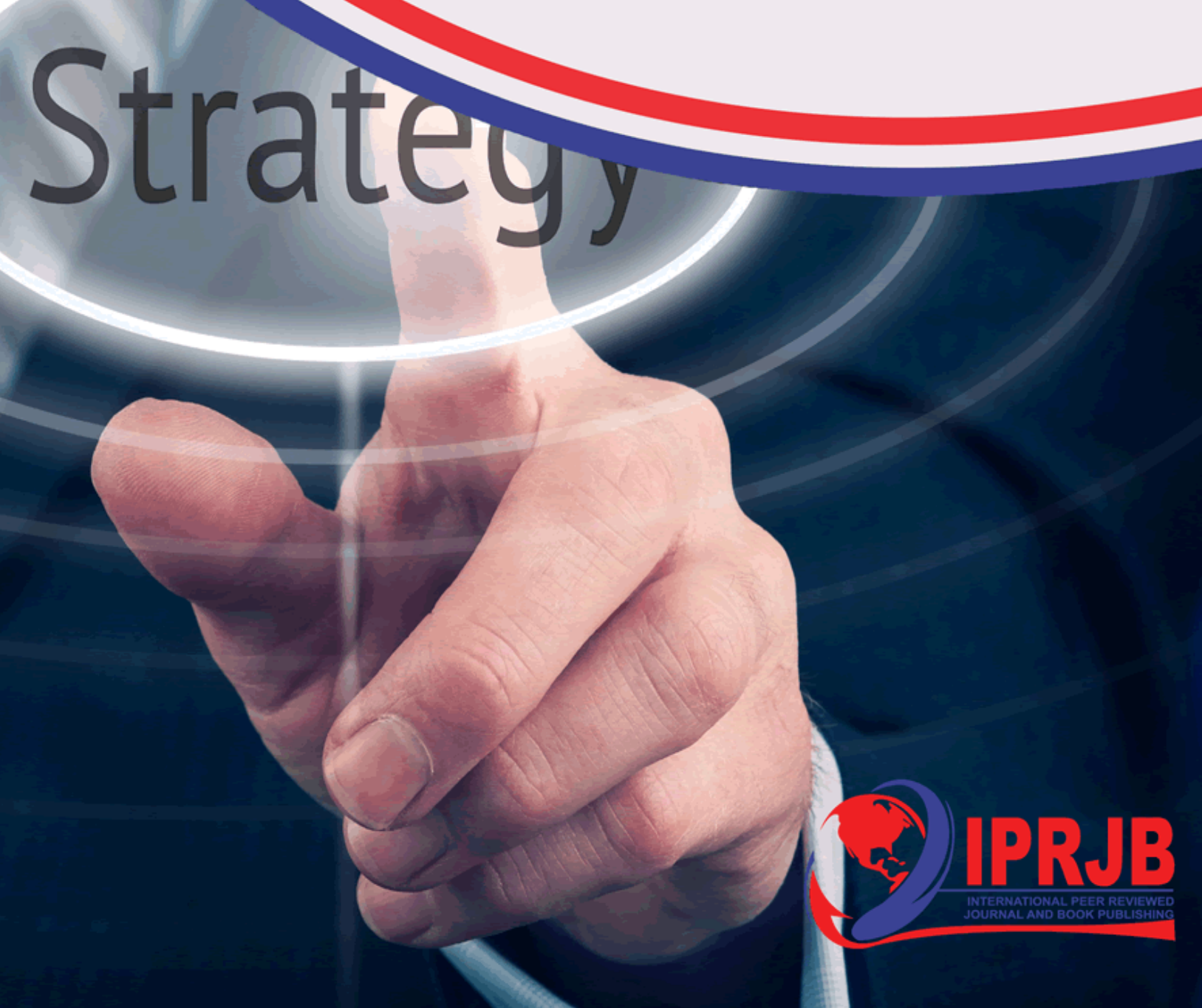




\title{
EFFECT OF TANGIBILITY ON CUSTOMER SATISFACTION AMONG MICRO FINANCE BANKS CUSTOMERS IN KENYA
}

\author{
${ }^{1}$ Hakim Omondi Nyabundi*; ${ }^{2}$ Dr. Victor Lusala Aliata, PhD; ${ }^{3}$ Dr. Alphonce Odondo, Phd* \\ Address For correspondence:

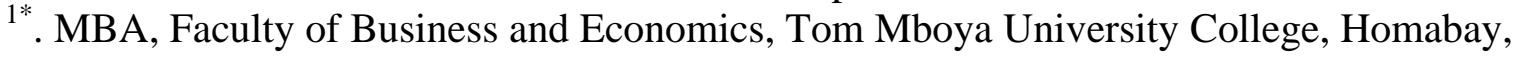 \\ Kenya \\ ${ }^{2}$ Lecturer, Faculty of Business and Economics, Tom Mboya University College, Homabay, \\ Kenya
}

\begin{abstract}
Purpose: Financial markets and institutions are central to the process of economic growth. The provision of credit has increasingly been regarded as an important tool for raising the incomes of populations, mainly by mobilizing resources to more productive uses. However, microfinance institutions in Kisumu City Kenya are still far off from reaching the required customer satisfaction index. The main purpose of the study was to establish the effect of tangibility on customer satisfaction among micro finance banks (MFB) customers in Kisumu City.

Methodology: This study was anchored on a Market based theory; Survival based theory and the Expectancy Disconfirmation theory. A correlation research design was used. Study targeted 10,300 MFB customers in Kisumu City. A sample size of 370 MFB customers was drawn from the target population using simple random sampling technique. The study used primary data from questionnaires.
\end{abstract}

Findings: The findings indicated that Tangibility is associated with $63.1 \%$ of the variation in customer satisfaction, an increase in tangibility affects customer satisfaction by 0.341 . The correlation analysis to determine the effect of tangibility on customer satisfaction shows a significant correlation existed $(\mathrm{r}=0.631, \mathrm{p}<0.05)$. This shows $63.1 \%$ of the variations on customer satisfaction are associated with tangibles.

Unique Contribution to Theory, Practice and Policy: The organization needs to train employees on various aspects of tangibility. Systems should be in place that ensures certain aspects like security and quality are retained and improved throughout customers' lifetime.

Keywords: Tangibility; Customer Satisfaction; Service Quality; Microfinance 


\section{INTRODUCTION}

Financial markets and institutions are central to the process of economic growth. The provision of credit has increasingly been regarded as an important tool for raising the incomes of populations, mainly by mobilizing resources to more productive uses (Atieno, 2001). The lending function is thus considered as the most important function for improving resource allocation and investment opportunities in a country. Therefore, Microfinance institutions have an important role in the financing of the economies, as they do most of the financial intermediation between depositors and borrowers of low income (Atieno, 2001).

Service can be defined as any intangible act or performance that a party offers to another that doesn't result in ownership of anything (Kotler et al, 2009). Gronroos, (1990) thus defines service quality as having two dimensions which are technical and functional dimensions or perceived and process dimensions. There are numerous service quality models of measurement that have been brought forward by various scientists but only few have been considered. The popular models embraced by various researchers are Nordic model, Multilevel model and SERVQUAL model. Nordic model by Gronroos, (1984) states that service quality is both technical (what consumers receive) and functional (how consumers receive the service) dimensions. This theory is based on the disconfirmation paradigm by comparing and contrasting perceived performance and expected service. This technique however failed to offer any measuring technique on technical and functional quality. Multilevel model by Dabholkar, P.A., Thorpe, D.I. \& Rentz, J.O. (1996) revised service quality model to a three stage model: primary dimensions, overall perceptions of service quality and sub dimensions. This model though is best suited for retail stores. SERVQUAL by Parasuraman et al. (1985) is a multi-dimensional research instrument, designed to capture consumers' expectations and perceptions of a service along five dimensions that are believed to represent service quality and that was founded ideally on the expectancy-disconfirmation theory. Studies show that when service quality dimensions; tangibility, reliability, responsiveness, assurance and empathy are positively applied, it usually results to customers being satisfied (Parasuraman et.al 1988; Gronroos, 1984). Moreover, the results of Agbor, (2011) study reveal that customer service quality has no significant direct relationship with customer satisfaction.

Significantly, even though numerous researchers have been able to link a positive relationship between service quality and customer satisfaction, there is also a fair share of studies that have indicated a weak and non-existent link such as Agbor, (2011); (Alemseged,2019).

Satisfaction may be defined as a person's feeling of pleasure or disappointment resulting from comparing a product's perceived performance or outcome in relation to his or her expectation (Kotler, 2000). Paul Farris, (2009) on the contrary, defines customer satisfaction as the number of customers, or percentage of total customers, whose reported experience with a firm, its products, or its services exceed specified satisfaction goals. This definition has been endorsed by the Marketing Accountability Standards Board as the standard definition. This latter definition has two implications; you can put a figure on satisfaction and also it has specified satisfaction goals concluding that it can either fall to the firm or customer to define the goals of service or product being offered.

Studies such as Kuo, (2011) and Agbor (2011) have noted and concluded that customer satisfaction level with regard to service quality is notably insignificant or if present is very 
minimal. Research such the ones mentioned above indicate an empirical gap of studies showing the respective agenda. Currently, the customer satisfaction state in respect to the country's microfinance sector remains largely grey. It is in this regard that this study seeks to clarify.

\section{LITERATURE REVIEW}

Suleiman, (2013) conducted a study on the impact of the basic dimensions of Servqual model on the level of customer satisfaction in dealing with the housing bank in Karak, Jordan. Employing a simple random sample of 375 questionnaires, data was gathered and scrutinized. An assessment of the statistical examination disclosed that tangible interpreted $47.8 \%$ of customer satisfaction.

Hussein, M and Aziz, R (2013) conducted a study on service quality dimensions and customer satisfaction of banks in Egypt also concluded that customer satisfaction in Egyptian banks is significantly influenced by Responsiveness, Assurance, Reliability and Empathy while the effect of the Tangible dimension does not have any notable footprint on customer satisfaction.

Yarhands et al., (2016) conducted a research on the impact of service quality on customer satisfaction in Obuasi Electricity Company of Ghana (ECG) from the customers' perspective. The questionnaires' used were analyzed using SPSS and Microsoft Excel. Simple regression was applied. Findings indicated that all five dimensions performed poorly $\mathrm{P}>0.05$. Tangibility was at -0.63 . Service quality in conclusively had a negative impact on customer satisfaction and concludes that the service quality deserves improvement.

Tibebe, (2012) conducted research on the impact of service quality on customer satisfaction at the public owned national alcohol and liquor factory. The study applied quantitative methodology and a self-completion questionnaire with closed questions. A sample of 300 was taken from 4200 customers in Addis Ababa. The study found that service quality dimensions had a positive relation with customer satisfaction and especially tangibility.

Suleiman, (2013); Saghier et al., (2013); Yarhands et al., (2016) and Tibebe, (2012) conducted research on the relationship between service quality and customer satisfaction and revealed mixed results. Suleiman, (2013) assessment of the statistical examination disclosed that tangible interpreted $47.8 \%$, which is clearly below average. Saghier et al., (2013) concluded that customer satisfaction in Egyptian banks is significantly influenced by Responsiveness, Assurance, Reliability and Empathy while the effect of the Tangible dimension does not have any notable footprint on customer satisfaction. Yarhands et al., (2016) findings indicated that all five dimensions performed poorly $\mathrm{P}>0.05$. Tangibility was at -0.63 . Service quality in conclusively had a negative impact on customer satisfaction and concludes that the service quality deserves improvement. Tibeke, (2012) study found that service quality dimensions had a positive relation with customer satisfaction and especially tangibility.

Muhamud, A. (2017) examined the relationship between service quality and customer satisfaction In Islamic banks. The findings showed that reliability and responsiveness had significant impact on the customer satisfaction. The study concluded a positive relationship between service quality and customer satisfaction; the correlation between reliability and 
customer satisfaction was low positive significant correlation $(\mathrm{r}=0.145, \mathrm{p}<.05)$. Muhamud suggests that there is a positive relationship between service quality and customer satisfaction and of the servqual dimensions, reliability was the key driver of service quality. This indicated that all five dimensions performed poorly $\mathrm{P}>0.05$. Tangibility was at -0.8 . Service quality in conclusively had a negative impact on customer satisfaction and concludes that the service quality deserves improvement.

Yarhands et al., (2016) conducted studies on the relationship between service quality and customer satisfaction and revealed both positive and negative results. The studies established that not all the five service quality dimensions (Empathy, Assurance, Tangibility, Reliability and Responsiveness) contribute to customer satisfaction. Naik et al., (2010) findings concluded that customers have highest expectation on the promptness of service, accuracy of transactions, security issues and concerns. Kuo et al., (2009) concluded that service quality positively affects both perceived value and customer satisfaction and especially assurance. Yarhands et al., (2016) indicated that all five dimensions performed poorly $\mathrm{P}>0.05$ with assurance at -0.61 . The analysis revealed that there is a significant positive correlation between service quality and customer satisfaction.

Ananth et al., (2010); examined the relationship between service quality and customer satisfaction and revealed inconclusive results. Ananth et al., (2010) findings also show that empathy, reliability and assurance positively affect service quality. Suharto, (2015) results suggest that four service quality dimensions (tangible, responsibility, responsiveness and assurance) are antecedents of consumer satisfaction in this industry, while empathy has no effect on customer satisfaction. This revealed that Servqual was a good model to measure bank service quality delivery in Tanzania context even though the study revealed that there is no significant positive relationship between empathy and customer satisfaction. The gap analysis carried out found pervasive evidence of negative disconfirmation. The study also confirmed linkages between service quality service quality and customer satisfaction.

\section{RESEARCH METHODOLOGY}

This study applied correlation research design. Correlation worked best for this thesis as it would aid in clearly drawing a comparison between service quality and customer satisfaction. The design measured two variables: independent and dependent variables. The independent variable is service quality and the dependent variable is customer satisfaction. The study was conducted in Kisumu City, Kenya. Geographically, it is located at the longitude of $0.0917^{\circ} \mathrm{S}$, and latitude $34.7680^{\circ} \mathrm{E}$. The total land area of Kisumu County totals $2085.9 \mathrm{~km}^{2}$. The study will focus on four microfinance banks in Kisumu City. According to the 2019 National Census of Kenya, the lakeside city has a total population of 1,155,574. This study area was ideal because despite it being a capital city, it represents only $3 \%$ of the latest survey population.

The target population was customers of microfinance banks in Kisumu. A total of 10,300 MFB customers obtained from the MFBs in Kisumu formed the universe of the study (CBK, 2018).

Since the sample was drawn from a large population of over 10,000 members, the sample size was determined according to the formula suggested by Mugenda (1999) below:

$$
\mathrm{n}=\mathrm{pqz}^{2} / \mathrm{e}^{2}
$$


Where;

$$
\begin{aligned}
& \mathrm{n}=\text { Minimized sized sample } \\
& \mathrm{p}=\text { Population proportion with given characteristic } \\
& \mathrm{q}=1-\mathrm{p} \\
& \mathrm{z}=\text { Standard normal deviate at the required confidence level } \\
& \mathrm{e}=\text { Error margin }
\end{aligned}
$$

Mugenda and Mugenda (1999, as contained in Fisher, Laing and Styoeckel, 1983) recommend that since $\mathrm{p}$ and $\mathrm{q}$ are unknown, both are set at $50 \%$. A confidence level of $95 \%$ was used for this study, $z=1.96$ and the sampling error of $e=+-5 \%$.

$$
\mathrm{n}=1.96^{2} \times 0.5 \times 0.5 / 0.05^{2}=384
$$

With a total population of $\mathrm{N}$ of 10,300 respondents, the adjusted minimum sample size $\mathrm{n}$ was determined according to de Vaus (2002)

$$
\begin{aligned}
\mathrm{n}^{\prime} & =\mathrm{n} / 1+\mathrm{n} / \mathrm{N} \\
\mathrm{n}^{\prime} & =384 / 1+384 / 10300 \\
& =370
\end{aligned}
$$

\begin{tabular}{|c|c|c|c|c|c|c|c|}
\hline & & $\begin{array}{l}\text { Tangi } \\
\text { bility }\end{array}$ & $\begin{array}{l}\text { Reliabilit } \\
\text { y }\end{array}$ & $\begin{array}{l}\text { Empath } \\
\mathrm{y}\end{array}$ & $\begin{array}{l}\text { Responsi } \\
\text { ve }\end{array}$ & $\begin{array}{l}\text { Assuranc } \\
\text { e }\end{array}$ & $\begin{array}{l}\text { Customer } \\
\text { Satisfactio } \\
n\end{array}$ \\
\hline Tangibility & $\begin{array}{l}\text { Pearson } \\
\text { Correlation } \\
\text { Sig. (2-tailed) }\end{array}$ & 1 & & & & & \\
\hline Reliability & $\begin{array}{l}\text { Pearson } \\
\text { Correlation } \\
\text { Sig. (2-tailed) }\end{array}$ & $\begin{array}{l}.615 \\
.000\end{array}$ & 1 & & & & \\
\hline Empathy & $\begin{array}{l}\text { Pearson } \\
\text { Correlation } \\
\text { Sig. (2-tailed) }\end{array}$ & $\begin{array}{l}.590 \\
.000\end{array}$ & $\begin{array}{l}.633 * * \\
.000\end{array}$ & 1 & & & \\
\hline
\end{tabular}

Where;

$$
\begin{aligned}
& \mathrm{n}^{\prime}=\text { Adjusted sample size } \\
& \mathrm{n}=\text { Minimized sized sample } \\
& \mathrm{N}=\text { Total population }
\end{aligned}
$$

\section{RESULTS}

The study applied the Pearson product moment correlation coefficient which is a measure of the strength of liner association between two variables. It was used to measure the degree of association between variables under consideration. Where the Pearson coefficient is less than 0.3 , the correlation is weak and 0.5 implies a strong correlation (Kothari,2004).

Table 1 : Correlations Coefficient 
European Journal of Business and Strategic Management

ISSN 2518-265X (Online)

Vol.6, Issue 2, No.2. pp 15 - 20, 2021

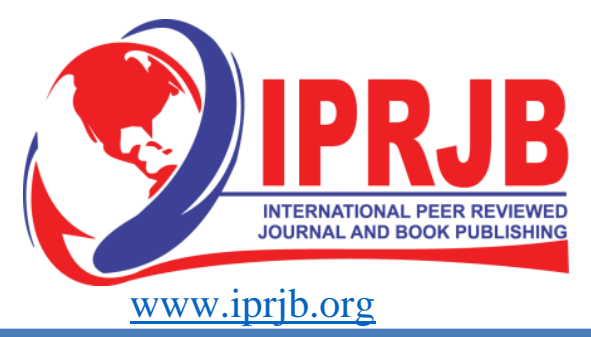

\begin{tabular}{|c|c|c|c|c|c|c|}
\hline \multirow[t]{2}{*}{ Responsive } & $\begin{array}{l}\text { Pearson } \\
\text { Correlation }\end{array}$ & .578 & .727 & $.540 * *$ & \multirow[t]{2}{*}{1} & \\
\hline & Sig. (2-tailed) & .000 & .000 & .000 & & \\
\hline Assurance & $\begin{array}{l}\text { Pearson } \\
\text { Correlation } \\
\text { Sig. (2-tailed) }\end{array}$ & $\begin{array}{l}.651 * \\
* \\
.000\end{array}$ & $\begin{array}{l}.726 * * \\
.000\end{array}$ & $\begin{array}{l}.685^{* *} \\
.000\end{array}$ & $\begin{array}{l}.775^{* *} \\
.000\end{array}$ & 1 \\
\hline $\begin{array}{l}\text { Customer } \\
\text { Satisfaction }\end{array}$ & $\begin{array}{l}\text { Pearson } \\
\text { Correlation } \\
\text { Sig. (2-tailed) }\end{array}$ & $\begin{array}{l}.631 * \\
*\end{array}$ & $.756^{* *}$ & $.695^{* *}$ & $\begin{array}{l}.715^{* *} \\
.000 \\
.000\end{array}$ & $.702 * *$ \\
\hline
\end{tabular}

**. Correlation is significant at 0.01 level (2-tailed)

The correlation analysis to determine the effect of tangibility on customer satisfaction shows a significant correlation existed $(r=0.631, p<0.05)$. This shows $63.1 \%$ of the variation on customer satisfaction are associated with tangibles. The correlation summary shown in Table 1 , therefore, indicates that the associations between tangibility and the dependent variable were significant.

The findings are consistent with views expressed by Ananth et al., (2010) who examined service quality gap analysis in private sector bank from a customer's perspective. Data was collected from 200 customers using structured questionnaires. Correlation analysis on the study also yielded positive correlation results ranging from .518 to .702 The findings also show that empathy, reliability and assurance positively affect service quality. An increase in empathy and reliability showed a positive increase in service quality. The study implies that banks should reduce the service gaps to deliver superior quality of service to retain existing customers as well as to attract new ones.

Multivariate regression analysis was used to determine the significance of the relationship between the dependent variable and all the independent variables pooled together. This analysis indicates how the independent variables influence the dependent variable collectively and to what extent each independent variable affects the dependent variable. The results are indicated in the model summary in Table 2

Table 2: Regression Coefficients results

\begin{tabular}{llllll}
\hline Model & Unstandardized Coefficients & & $\begin{array}{l}\text { Standardized } \\
\text { Coefficients }\end{array}$ & T & Sig. \\
\cline { 2 - 6 } & B & Std. Error & Beta & .562 & .003 \\
\hline (Constant) & 1.427 & 2.091 & & 3.4888 & .002 \\
Tangibility & .314 & .090 & .413 & 2.64166 & .002 \\
Reliability & .329 & .314 & .376 & 2.8737 & .001 \\
Empathy & .296 & .103 & .302 & 2.51764 & .001 \\
Responsive & .214 & .085 & .249 & 2.5384 & .002 \\
Assurance & .297 & .117 & .414 & & \\
\hline
\end{tabular}


a. Dependent Variable: Customer Satisfaction

From the analyzed data in table 4.14 the established regression equation was:

$\mathrm{Y}=1.427+0.314 \mathrm{X}_{1}+0.325 \mathrm{X}_{2}+0.296 \mathrm{X}_{3}+0.214 \mathrm{X}_{4}+0.297 \mathrm{X}_{5}$

Tangibility, Reliability, Empathy, Responsive, Assurance

$\mathrm{X}_{1}$ is Tangibility, $\mathrm{X}_{2}$ is Reliability, $\mathrm{X}_{3}$ is Empathy, and $\mathrm{X} 4$ is Responsive while $\mathrm{X}_{5}$ is Assurance. From the above linear regression model, all independent variables have a positive coefficient. This shows that there is a positive relationship between the dependent variable; Customer satisfaction and independent variables; Tangibility, Reliability, Empathy, Responsive and Assurance.

The unstandardized coefficients can be interpreted to show they change in the dependent variable which in our case is customer's satisfaction due to a change in the independent variables by 1 unit.

This means that if tangibility is increased or decreased by 1 unit it will affect customer satisfaction measurement by .341 . if reliability, empathy, responsiveness and assurance are increased or decreased by 1 unit they will affect the measure of customer satisfaction by .329 , $.296, .214$ and .297 coefficients respectively.

The findings clearly indicate that the respondents felt that reliability was the most essential to their satisfaction being met. If the microfinance banks improve their reliability in service delivery and customer care it will greatly help increasing the customer satisfaction rate. This also applies to tangibility, empathy, responsiveness and assurance.

\section{CONCLUSION}

Tangibility proved to be highly relevant and useful in the MFBs. Customers are visual beings and what they see, touch feel or smell has an impression on their satisfaction of a product or service.

Tangibility is associated with $63.1 \%$ of the variation in customer satisfaction as evident by the respondents' data. This shows there is a strong relationship between tangibility and customer satisfaction. An increase in tangibility affects customer satisfaction by .341 .

\section{RECOMMENDATION}

The employees ought to embrace tangibility and the other factors to positively reflect on customer satisfaction. Organizations should purpose to improve the tangibles as this will help improve the customer's satisfaction score.

\section{.REFERENCES}

Agbor, J.M. (2011).The relationship between Customer Satisfaction and Service Quality. A study of three service sectors in Umea, Published thesis; Umea School of Business, Umea University, www.Usbe.umu.se.

Alemseged, M. (2019). The effect of service quality on customer satisfaction; In the case of main department of immigration and Nationality affairs in Addis Ababa bole international airport branch. 
Ananth, A., Ramesh, R. \& Prabaharan, B. (2011). Service quality GAP analysis in private sector banks, a customer perspective. Internationally Indexed Journal, 11(1), 242 252.

Atieno R. (2001). Formal and informal institutions' lending policies and access to credit by small-scale

enterprises in Kenya: An empirical assessment.

Central bank of Kenya (2018). Bank supervision Annual report 2018, Nairobi.

Dabholkar, P.A., Thorpe, D.I. \& Rentz, J.O. (1996). A measure of service quality for retail stores: Scale development and validation.

Farris, P. (2009). Key marketing metrics: The 50+ metrics every manager needs to know (Rev.). Pearson Education UK.

Grönroos, C. (1984). A Service Quality Model and its Marketing Implications. European. Journal of Marketing, 18 (4), 36-44.

Gronroos, C. (1990). Service Management and Marketing: managing the moments of truth in service competition. Lexington Books, Lexington.

Kotler, P. (2000). Marketing Management (10th ed.). New Jersey: Prentice-Hall.

Kotler, P., \& Keller, K.L. (2009). Marketing Management (12th ed.). New Jersey: Pearson Education Inc.

Mugenda, O., \& Mugenda, A.(1999). Research Methods. Quantitative approaches, Nairobi African centre of Technology studies.

Parasuraman, A., Zeithaml, V., \& Berry, L. L. (1985). A conceptual model of service quality and its implications for future research. Journal of marketing, 49 (4), 41-50.

Parasuraman, A., Zenithal, V.A. \& Berry, L. L. (1988). SERVQUAL: A multiple- item scale for measuring consumer perceptions of service quality. Journal of retailing, 64 (1), $12-40$.

Sulieman, A,: (2013). Basic dimensions of the (servqual model) and its impact on the level of customer satisfaction: an empirical study of the housing bank in Karak, Jordan

Tibebe, Z (2012): Impact of service quality on customer satisfaction at the public owned National

Alcohol and Liquor Factory.

Yarhands, D. A et Al (2016), The impact of Service quality on customer satisfaction in Obuasi Electricity Company of Ghana (ECG) - The customers perspective 